ISSN 2338-1523

E-ISSN 2541-576X

Volume 7 No. 1

Mei 2019

\title{
PENGARUH SOCIAL MEDIA MARKETING TERHADAP BRAND EQUITY (Studi Kasus Pada SMK Permata Harapan)
}

\author{
Rudi Yanto Batara Silalahi \\ Akademi Akuntansi Permata Harapan \\ email: rudisilalahi16@gmail.com
}

\begin{abstract}
This study is aimed to determine the effect of social media marketing on brand equity. The population in this study are students of SMK Permata Harapan. this study use non probability sampling methode with purposive sampling technique to obtain a sample of 40 people. The results of this study found social media marketing affect the brand equity of SMK Permata Harapan

Penelitian ini bertujuan untuk mengetahui pengaruh social media marketing terhadap brand equity. Adapun populasi dalam penelitian ini yaitu siswa SMK Permata Harapan dan pengambilan sampel mengunakan non probability sampling dengan teknik purposive sampling sehingga diperoleh sampel sebanyak 40 orang. Hasil penelitian ini social media marketing berpengaruh signifikan terhadap brand equity SMK Permata Harapan.
\end{abstract}

Keywords: social media marketing, brand equity

\section{PENDAHULUAN}

Semakin berkembangannya teknologi tentu membawa perubahan dalam segala bidang, tidak terkecuali bidang marketing. Dimana dahulu orang bertransaksi antara penjual dan pembeli secara konvensional dengan bertatap muka secara langsung, kini dengan perkembangan teknologi semua transaksi jual beli dapat dilakukan melalui satu media melalui jaringan internet tanpa bertemu secara langsung.

Pemasaran dengan memanfaatkan media internet disebut internet marketing atau electronic marketing (e-marketing) (Zulfikar \& Jurusan, 2017). Marketing bisa dengan menggunakan media sosial facebook, whattsap, Instagram, Youtube, Website, dll. Media sosial tersebut bisa digunakan sebagai wadah promosi untuk mempengaruhi pembeli untuk menggunakan produk atau jasa yang ditawarkan oleh penjual. Media sosial menurut Philip Kotler dan Kevin Keller dalam (Walid, 2018), merupakan sarana bagi konsumen untuk berbagi informasi teks, gambar, audio, dan video dengan satu sama lain dan dengan perusahaan dan sebaliknya. Dengan semakin berkembangnya dunia pemasaran saat ini, sosial media pun dijadikan tempat pemasaran bagi perusahaan karena ratarata penggunaan internet untuk media sosial di Indonesia adalah selama dua jam dua puluh tiga menit untuk setiap harinya (Kusuma \& Putri, 2019).

Peran media sosial menurut (Wulan \& Dkk, 2016) adalah :

1. Memberikan identitas perusahaan, produk atau jasa yang ditawarkan,

JURSIMA https://ejournal.giciku.ac.id/ 
ISSN 2338-1523

E-ISSN 2541-576X

Volume 7 No. 1

Mei 2019

2. Membantu menciptakan hubungan dengan orang yang tidak mengenal produk dan jasa perusahaan,

3. Membuat perusahaan "real" terhadap konsumen, perusahaan tidak hanya membicarakan produknya tapi juga personality mereka,

4. Mengasosiasikan diri dan rekannya yang dapat melayani target pasar yang sama,

5. Untuk berkomunikasi dan berinteraksi apa yang dicari konsumen.

Dengan begitu pentingnya peranan media sosial dalam pemasaran diharapkan dapat memerkenalkan produk atau jasa yang dipromosikan serta mempengaruhi konsumen untuk mengunakan produk atau jasa yang ditawarkan lewat media tersebut. Perkembangan media sosial saat ini sangat memungkinkan perusahaan atau pemilik bisnis memasarkan produk/jasanya dengan pendekatan baru yaitu dengan social media marketing, (Widyawati \& Hidayat, 2018).

Menurut David A.Aker dalam (Kinanti \& Putri, 2017) brand equity adalah sekumpulan aset dan kewajiban (liabilities) merek yang berkaitan dengan sebuah merek, nama dan simbolnya, yang berdampak pada pengurangan atau penambahan nilai yang diberikan oleh sebuah produk atau jasa kepada perusahaan maupun pelanggan. Sedangkan brand equity menurut menurut Kotler \& Keller dalam (Wulan \& Dkk, 2016) adalah: "Nilai tambah yang diberikan oleh produk atau jasa. Nilai ini bisa dicerminkan dalam cara konsumen berpikir, merasa dan bertindak terhadap brand, harga, pangsa pasar dan profitabilitas perusahaan. Sehingga dapat disimpulkan brand equity merupakan nilai tambah dari sebuah produk atau jasa tehadap merek yang mempengaruhi merek

tersebut dimata pelanggan maupun perusahaan.

Menurut David A. Aker dalam (Kinanti \& Putri, 2017) brand equity dapat terbentuk oleh kontribusi empat dimensi aset merek:

1. Brand awareness: Kesanggupan seorang calon pembeli untuk mengenali atau mengingat kembali suatu merek sebagai bagian dari suatu kategori produk tertentu.

2. Brand associations: Segala hal yang memiliki keterkaitan dengan ingatan/memori mengenai suatu merek tertentu baik secara rasional dan emosional.

3. Perceived quality: Penilaian dan evaluasi yang bersifat subjektif dari pelanggan mengenai kualitas dan keunggulan dari suatu produk atau jasa secara keseluruhan

4. Brand loyalty: Suatu ukuran yang menunjukan sejauh mana keterkaitan antara konsumen dengan suatu merek tertentu yang mempengaruhi kemungkinan konsumen akan beralih atau tidak ke merek produk atau jasa lainnya.

Bagi pelanggan, ekuitas merek dapat memberikan nilai dalam memperkuat pemahaman mereka akan proses informasi, memupuk rasa percaya diri dalam pembelian, serta meningkatkan pencapaian kepuasan (Nur Latifa Isnaini P, Fauziyyah, \& H, 2017). Tingkat kesadaran konsumen terhadap suatu merek (brand awareness) sangatlah penting bagi sebuah perusahaan atau organisasi untuk menyediakan produk yang benar-benar dibutuhkan oleh konsumen (Walid, 2018).

Setiap pelaku bisnis dapat membangun brand yang dimilikinya, salah satunya dengan menggunakan media sosial sebagai

JURSIMA https://ejournal.giciku.ac.id/

Jurnal Sistem Informasi dan Manajemen 
wadah untuk pemasaran produk atau jasa yang ditawarkan. Social media marketing adalah segala bentuk pemasaran langsung atau tidak langsung yang digunakan untuk membangun kesadaran, pengenalan, pengingatan kembali, dan pengambilan aksi terhadap sebuah brand, bisnis, produk, orang, atau hal lainnya yang dikemas menggunakan alat- alat di social web, seperti blogging, microblogging, social networking, social bookmarking, dan content sharing (Gunelius dalam (Ratana, 2018)).

Social media marketing adalah teknik marketing yang menggunakan sosial media sebagai sarana untuk mempromosikan suatu produk (link halaman website bisnis online) atau suatu jasa, atau produk lainnya secara lebih spesifik (Walid, 2018). Jadi dapat disimpukan sosial media marketing merupakan promosi yang dilakukan dengan memanfaatkan media sosial untuk berbagi informasi mengenai produk atau jasa yang ditawarkan. Menurut Heuer dalam (Kusuma \& Putri, 2019) terdapat 4C dalam penggunaan media sosial, yaitu:

1. Context: Penggunaan bahasa maupun isi dari pesan yang akan disampaikan seperti kejelasan dari pesan dan pemilihan kata-kata yang mudah dipahami dan menarik.

2. Communication: Berbagi pesan dengan cara membuat pengguna merasa nyaman dan pesan tersampaikan dengan baik seperti memberikan informasi yang up to date dan respon admin yang menjawab pertanyaan pada media sosial haruslah baik.

3. Collaboration: Membuat khalayak melihat postingan suatu brand dan terlibat dalam memberikan like ataupun comment bahkan menyebarkan pada temannya maka hal tersebut akan lebih efektif dalam pemasaran media sosial tersebut.

4. Connection: Perusahaan harus dapat memelihara hubungan yang telah dibuat.

Dengan adanya media sosial marketing ini informasi dapat disebarkan dengan secara luas dan mudah, sehingga perusahaan harus mengemas informasi tersebut menjadi konten yang menarik yang mampu untuk diperbincangkan oleh khalyak atau konsumen (Kusuma \& Putri, 2019).

Jika pelanggan tidak tertarik pada suatu merek dan membeli karena karakteristik produk, harga, kenyamanan, dan dengan sedikit mempedulikan merek, kemungkinan brand equity-nya rendah, sedangkan jika para pelanggan cenderung membeli suatu merek walaupun dihadapkan pada para pesaing yang menawarkan produk yang lebih unggul, misalnya dalam hal harga dan kepraktisan maka merek tersebut memiliki brand equity yang tinggi (Irwan et al dalam (Noviani Sari Angkie \& Tanoto, 2019)).

Salah satu media social marketing yang memuat informasi secara detail adalah website. Website adalah halaman informasi yang disediakan melalui jalur internet sehingga bisa diakses di seluruh dunia selama terkoneksi dengan jaringan internet. Website merupakan komponen atau kumpulan komponen yang terdiri dari teks, gambar, suara animasi sehingga lebih merupakan media informasi yang menarik untuk dikunjungi (Wulan \& Dkk, 2016). Dimana dengan adanya media sosial website di sekolah maka pihak sekolah dapat berbagi informasi baik mengenai kegiatan akademik maupun non akademik yang dapat dengan mudah diakses.

JURSIMA https://ejournal.giciku.ac.id/ 
SMK Permata Harapan merupakan salah satu SMK swasta yang ada di Kota Batam. Dimana saat ini SMK Permata Harapan memiliki 3 jurusan yaitu akuntansi, marketing, dan rekayasa perangkat lunak.

\section{Tabel 1. Peringkat 10 Besar Ujian Nasioanal SMK Se Kepulauan Riau Tahun 2017/2018}

\begin{tabular}{|c|l|c|c|c|}
\hline No & \multicolumn{1}{|c|}{ NAMA SEKOLAH } & $\begin{array}{c}\text { JUMLAH } \\
\text { PESERTA }\end{array}$ & $\begin{array}{c}\text { JUMLAH } \\
\text { NILAI }\end{array}$ & $\begin{array}{c}\text { PERING } \\
\text { KAT }\end{array}$ \\
\hline 1 & SMK MAITREYAWIRA BATAM & 104 & 71,08 & 1 \\
\hline 2 & SMK YEHONALA BATAM & 26 & 68,01 & 2 \\
\hline 3 & SMK GLOBE NATIONAL PLUS BATAM & 11 & 67,06 & 3 \\
\hline 4 & SMK BATAM BUSINESS SCHOOL & 55 & 66,35 & 4 \\
\hline 5 & SMK PERMATA HARAPAN BATAM & 139 & 64,66 & 5 \\
\hline 6 & SMK PUTRA BATAM & 19 & 63,80 & 6 \\
\hline 7 & SMK NEGERI 2 BATAM & 400 & 63,37 & 7 \\
\hline 8 & $\begin{array}{l}\text { SMKIT DARUSSALAM BOARDING } \\
\text { SCHOOL 01 BATAM }\end{array}$ & 3 & 62,63 & 8 \\
\hline 9 & SMK HARAPAN UTAMA BATAM & 28 & 62,50 & 9 \\
\hline 10 & SMK NEGERI 1 TANJUNGPINANG & 491 & 60,90 & 10 \\
\hline Sul & & & \\
\hline
\end{tabular}

Sumber: https://disdik.kepriprov.go.id, 2019

Berdasarkan tabel 1, secara kualitas pembelajaran SMK Permata Harapan memiliki kualitas pembelajaran yang baik, hal ini dapat dilihat dari hasil yang diraih SMK Permata Harapan yang berada diperingkat ke 5 untuk nilai Ujian Nasional SMK se Kepulauan Riau tahun pelajaran 2017/2018. Dengan keadaan seperti ini untuk meningkatkan informasi akan berbagai keunggulan maupun kegiatan akademik yang dimilikinya, SMK Permata Harapan sudah memiliki media sosial tersediri sehingga orang luar baik itu orang tua, siswa, atau masyarakat luas dapat mengetahuinya informasi baik kegiatan akademik maupun non akademik tanpa perlu bertemu secara langsung.

Adapun media sosial marketing yang digunakan oleh SMK Permata Harapan untuk promosi dan berbagi informasi seperti chanel youtube SPH Production, Instagram @permataharapanku, dan website smk.permataharapanku.sch.id. Dengan media sosial marketing tersebut diharapakan dapat memperkuat brand equity baik terhadap pelanggan maupun perusahaan sehingga orang lain dapat dengan mudah mengingat SMK Permata Harapan karena nila tambah yang diciptakan dari merek SMK Permata Harapan.

Berdasarkan fenomena dan identifikasi masalah diatas maka peneliti membatasi masalah sosial media marketing serta satu masalah brand equity. Adapun rumusan masalah pada penelitian ini yaitu, apakah media social marketing berpengaruh terhadap brand equity pada SMK Permata Harapan?

\begin{tabular}{|c|c|c|}
\hline $\begin{array}{l}\text { Social Media } \\
\text { Marketing (X) }\end{array}$ & $\mathrm{H} 1$ & $\begin{array}{c}\text { Brand Equity } \\
\text { (Y) }\end{array}$ \\
\hline
\end{tabular}

\section{Gambar 1. Kerangka Pemikiran}

Berdasarkan kerangka pemikiran dan rangkai teori di atas, maka hipotesis untuk penelitian ini dirumuskan sebagai berikut, social media marketing berpengaruh signifikan terhadap brand equity.

\section{METODE PENELITIAN}

Penelitian ini termasuk penelitian kuantitatif asosiatif, karena penelitian ini mencari pengaruh sebab akibat antara variabel independent terhadap variabel dependennya. Dimana variabel independen dalam penelitian ini adalah social media marketing dan variabel dependennya yaitu brand equity. Penelitian ini dilakukan di SMK Permata Harapan yang beralamat di Komp. Batu Batam Mas Blok D \& E No. 1-2-3 Pulau Batam.

Populasi pada penelitian ini yaitu siswa SMK Permata Harapan. Sedangkan sampel pada penelitian ini sebanyak 40 orang. Penelitian ini menggunakan teknik pengambilan sampel non probability

JURSIMA https://ejournal.giciku.ac.id/ 
Volume 7 No. 1

Mei 2019

sampling, karena tidak memberikan kesempatan yang sama bagi populasi untuk menjadi sampel. Teknik nonprobability sampling yang digunakan adalah purposive sampling, di mana teknik penentuan sampel menggunakan kriteria tertentu yang telah ditentukan oleh peneliti (Sugiono dalam (Ratana, 2018). Adapun kriteria purposive sampling dalam penelitian ini yaitu:

1. Siswa SMK Permata Harapan yang masih aktif di tahun pelajaran 2018/2019

2. Pernah melihat dan tertarik terhadap salah satu media sosial marketing SMK Permata Harapan.

Teknik pengumpulan data yang digunakan adalah kuesioner. Kuisioner dibuat berdasarkan indikator dimana untuk variabel brand equity (Y) terdiri dari 4 indikator dan dijabarkan menjadi 8 item pernyataan sedangkan untuk variabel social media marketing $(\mathrm{X})$ terdiri dari 5 indikator dan dijabarkan menjadi 8 item pernyataan. Adapun defenisi operasional variabel dirangkum di tabel 2 .

Tabel 2. Defenisi Operasional Variabel

\begin{tabular}{|c|c|c|c|}
\hline Variabel & Konsep & Indikator & Skala \\
\hline $\begin{array}{l}\text { Sosial } \\
\text { Media } \\
\text { Marketing } \\
\left(X_{1}\right)\end{array}$ & $\begin{array}{l}\text { Proses promosi } \\
\text { dengan } \\
\text { menggunakan } \\
\text { media sosial }\end{array}$ & $\begin{array}{l}\text { 1. Participation } \\
\text { 2. Openness } \\
\text { 3. Conversatio } \\
\text { 4. Community } \\
\text { 5. Connectednes }\end{array}$ & Likert \\
\hline $\begin{array}{l}\text { Brand } \\
\text { Equity }(Y)\end{array}$ & $\begin{array}{lr}\text { Nilai } & \text { tambah } \\
\text { dari } & \text { sebuah } \\
\text { produk atau jasa }\end{array}$ & $\begin{array}{l}\text { 1. Brand } \\
\text { awareness } \\
\text { 2. Perceived } \\
\text { quality } \\
\text { 3. Brand } \\
\text { association } \\
\text { 4. Brand loyalty }\end{array}$ & Likert \\
\hline
\end{tabular}

Sumber: Literatur Riview, 2019

Teknik analisis data dalam penelitian ini yaitu uji validitas, reliabilitas, uji normalitas, uji heterokedasitas, multikolinearitas, analisis regresi, uji hipotesis, dan koefisien determinasi.

\section{HASIL DAN PEMBAHASAN}

\section{Uji Validitas}

Berdasarkan tabel 3 dan tabel 4 dapat dilihat bahwa seluruh item pernyataan variabel social media marketing dan variabel brand equity memiliki koefisien korelasi diantara 0,344 - 0,784 > 0,3 sehingga seluruh item pernyataan dalam penelitian ini dinyatakan valid

\section{Tabel 3. Hasil Uji Validitas Social} Media Marketing

\begin{tabular}{|c|c|c|c|c|}
\hline $\begin{array}{l}\text { Variab } \\
\text { el }\end{array}$ & $\begin{array}{l}\text { Pern } \\
\text { yata } \\
\text { an }\end{array}$ & $\begin{array}{l}\text { Koefisie } \\
\text { n } \\
\text { Korelasi }\end{array}$ & $\begin{array}{l}\text { Corrected } \\
\text { item total } \\
\text { correlation }\end{array}$ & $\begin{array}{l}\text { Kesi } \\
\text { mpul } \\
\text { an }\end{array}$ \\
\hline \multirow{8}{*}{$\begin{array}{l}\text { Social } \\
\text { Media } \\
\text { Market } \\
\text { ing }\end{array}$} & $\mathrm{X} 1$ & 0,596 & 0,3 & Valid \\
\hline & $\mathrm{X} 2$ & 0,413 & 0,3 & Valid \\
\hline & X3 & 0,466 & 0,3 & Valid \\
\hline & $\mathrm{X} 4$ & 0,437 & 0,3 & Valid \\
\hline & $\mathrm{X} 5$ & 0,443 & 0,3 & Valid \\
\hline & X6 & 0,510 & 0,3 & Valid \\
\hline & $\mathrm{X} 7$ & 0,607 & 0,3 & Valid \\
\hline & X8 & 0,350 & 0,3 & Valid \\
\hline
\end{tabular}

Sumber: Data diolah SPSS, 2019

Tabel 4. Hasil Uji Validitas Brand Equity

\begin{tabular}{|l|l|c|c|l|}
\hline $\begin{array}{l}\text { Variab } \\
\text { el }\end{array}$ & $\begin{array}{l}\text { Pern } \\
\text { yataa } \\
\text { n }\end{array}$ & $\begin{array}{l}\text { Koefisie } \\
\text { n }\end{array}$ & $\begin{array}{l}\text { Corrected } \\
\text { Korelasi total }\end{array}$ & $\begin{array}{l}\text { Kesi } \\
\text { mpul } \\
\text { correlation }\end{array}$ \\
\hline \multirow{3}{*}{$\begin{array}{l}\text { Brand } \\
\text { Equity }\end{array}$} & Y1 & 0,689 & 0,3 & Valid \\
\cline { 2 - 5 } & Y2 & 0,704 & 0,3 & Valid \\
\cline { 2 - 5 } & Y3 & 0,662 & 0,3 & Valid \\
\cline { 2 - 5 } & Y4 & 0,784 & 0,3 & Valid \\
\cline { 2 - 5 } & Y5 & 0,457 & 0,3 & Valid \\
\cline { 2 - 5 } & Y6 & 0,519 & 0,3 & Valid \\
\cline { 2 - 5 } & Y7 & 0,476 & 0,3 & Valid \\
\cline { 2 - 5 } & Y8 & 0,344 & 0,3 & Valid \\
\hline
\end{tabular}

Sumber: Data diolah SPSS, 2019

\section{Uji Reliabilitas}

Berdasrkan tabel 5, dapat dilihat nilai Cronbach alpha untuk variabel social media marketing dan brand equity 0,774 dan 0,846 lebih besar dari 0,6. Sehingga 
ISSN 2338-1523

E-ISSN 2541-576X

Volume 7 No. 1

Mei 2019

dapat disimpulkan kedua variabel tersebut reliabel.

Tabel 5. Hasil Uji Reliabilitas

\begin{tabular}{|l|l|l|l|}
\hline Variabel & $\begin{array}{l}\text { Cronbach's } \\
\text { Alpha }\end{array}$ & Batas & Kesimpulan \\
\hline $\begin{array}{l}\text { Social } \\
\text { Media } \\
\text { Marketing }\end{array}$ & 0,774 & 0,6 & Reliabel \\
\hline $\begin{array}{l}\text { Brand } \\
\text { Equity }\end{array}$ & 0,846 & 0,6 & Reliabel \\
\hline
\end{tabular}

Sumber: Data diolah SPSS, 2019

\section{Uji Normalitas}

Uji Normalitas pada penelitian ini menggunakan uji Kolmogrov Smirnov, dimana kriteria pengambilan keputusannya jika nilai signifikansinya lebih besar dari 0,05 maka data berdistribusi normal.

Tabel 5. Hasil Uji Normalitas

One-Sample Kolmogorov-Smirnov Test

\begin{tabular}{|c|c|c|}
\hline & & $\begin{array}{c}\text { Unstandardized } \\
\text { Residual }\end{array}$ \\
\hline $\mathrm{N}$ & & 40 \\
\hline & Mean & $0 \mathrm{E}-7$ \\
\hline Normal Parameters ${ }^{a, b}$ & $\begin{array}{l}\text { Std. } \\
\text { Deviation }\end{array}$ & 3.05504424 \\
\hline & Absolute & .140 \\
\hline Most Extreme Differences & Positive & .106 \\
\hline & Negative & -.140 \\
\hline Kolmogorov-Smirnov $Z$ & & .885 \\
\hline Asymp. Sig. (2-tailed) & & .414 \\
\hline
\end{tabular}

Berdasarkan tabel 5 dapat dilihat nilai asymp sig lebih 0,414 lebih besar dari 0,05 , sehingga data dalam penelitian ini berdistribusi normal.

\section{Uji Heterokedasitas}

Penelitian ini menggunakan scatterplot untuk penguji heterokedasitas. Dimana pada gambar 2 dapat dilihat titik- titik menyebar secara acak serta tersebar baik di atas maupun di bawah angka nol pada sumbu Y. Sehingga dapat disimpulkan penelitian ini terbebas dari gejala heterokedasitas.

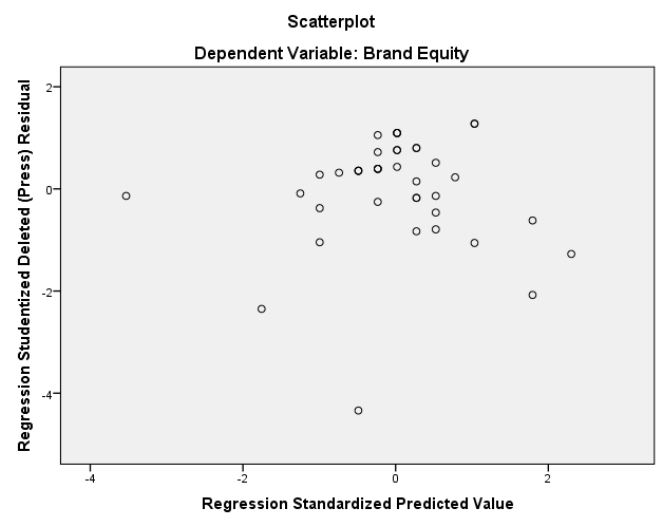

Gambar 2. Scatterplot

\section{Uji Multikolinearitas}

Berdasarkan tabel 6 dapat dilihat nilai VIF social media marketing sebesar 1,000 lebih besar dari pada 10 dan nilai tolerance 1,000 lebih besar dari 0,1 . Sehingga pada penelitian ini dapat disimpulkan bahwa penelitian ini tidak terjadi multikolineritas dalam model regresinya.

\section{Tabel 6. Hasil Uji Multikolinearitas} Coefficientsa

\begin{tabular}{|l|l|l|l|l|c|}
\hline \multirow{2}{*}{ Model } & \multicolumn{3}{|c|}{ Correlations } & \multicolumn{2}{c|}{ Collinearity Statistics } \\
\cline { 2 - 6 } & Zero-order & Partial & Part & Tolerance & VIF \\
\hline \multirow{2}{*}{$\begin{array}{l}\text { (Constant) } \\
\text { Social Media Marketing }\end{array}$} & & & & & \\
\hline
\end{tabular}

Sumber: Data diolah SPSS, 2019

\section{Analisis Regresi Sederhana}

Berdasarkan tabel 7. Dapat disimpulkan persamaan regresi pada penelitian ini, yaitu:

$\mathrm{Y}=3,154+0,880 \mathrm{X}$

1. Dari persamaan regresi sederhana diketahui nilai konstanta sebesar 3,154 menunjukan bahwa ketika media sosial marketing bernilai nol

JURSIMA https://ejournal.giciku.ac.id/ 
Volume 7 No. 1

Mei 2019

(0) dan tidak ada perubahan maka brand equity SMK Permata Harapan adalah positif sebesar 3,154.

2. Hal ini menunjukan bahwa apabila variabel social media marketing meningkat sebesar satu-satuan maka brand equity (Y) SMK Permata Harapan akan meningkat sebesar 0.880 atau $88,00 \%$ dengan asumsi variabel lain tetap.

Tabel 7. Tabel Coeficients

\begin{tabular}{|c|c|c|c|c|c|}
\hline \multirow[t]{2}{*}{ Model } & \multicolumn{2}{|c|}{$\begin{array}{l}\text { Unstandardized } \\
\text { Coefficients }\end{array}$} & \multirow{2}{*}{$\begin{array}{c}\text { Standardized } \\
\text { Coefficients }\end{array}$} & \multirow[t]{2}{*}{ t } & \multirow[t]{2}{*}{ Sig. } \\
\hline & B & Std. Error & & & \\
\hline \multirow{2}{*}{$1 \begin{array}{l}\text { (Constant) } \\
\text { Social Media Marketing }\end{array}$} & 3.154 & 3.667 & & .860 & .395 \\
\hline & .880 & .126 & .751 & 7.002 & . 000 \\
\hline
\end{tabular}

\section{Uji Hipotesis}

Pengujian dilakukan dengan melihat taraf signifikansi (pvalue), jika taraf signifikansi yang dihasilkan dari perhitungan di bawah 0,05 maka hipotesis diterima, sebaliknya jika taraf signifikansi hasil hitung lebih besar dari 0,05 maka hipotesis ditolak, (Azman, 2019).

Tabel 8. Uji Hipotesis ANOVA $^{\mathrm{a}}$

\begin{tabular}{|l|r|r|r|r|r|}
\hline Model & $\begin{array}{c}\text { Sum of } \\
\text { Squares }\end{array}$ & df & $\begin{array}{c}\text { Mean } \\
\text { Square }\end{array}$ & F & Sig. \\
\hline $\begin{array}{l}\text { Regressio } \\
\mathrm{n}\end{array}$ & 469.601 & 1 & 469.601 & $\begin{array}{r}49.0 \\
25\end{array}$ & $.000^{\mathrm{b}}$ \\
1 Residual & 363.999 & 38 & 9.579 & & \\
Total & 833.600 & 39 & & & \\
\hline
\end{tabular}

a. Dependent Variable: Brand Equity

b. Predictors: (Constant), Social Media Marketing Sumber: Data diolah SPSS, 2019

Berdasarkan Tabel 8 Dapat dilihat bahwa hipotesis diterima karena nilai signifikansi 0,000 lebih kecil dari pada 0,05 , sehingga disimpulkan sosial media marketing berpengaruh signifikan terhadap brand equity SMK Permata
Harapan. Hasil penelitian ini sesuai dengan penelitian yang dilakukan oleh Kusuma dan Putri (2019), bahwa social media marketing berpengaruh terhadap brand equity.

\section{Uji Koefisien Determinasi}

Dari Tabel 9. Dapat dilihat nilai $R$ Square sebesar 0,563, ini artinya 56,30\% variabel brand equity dapat dijelaskan oleh variabel social media marketing sedangkan sisanya $43,70 \%$ dapat dijelaskan oleh variabel lain yang tidak dijelaskan dalam model regresi ini.

Tabel 9. Koefisien Determinasi Model Summary

\begin{tabular}{|l|r|r|r|r|}
\hline Model & $\mathrm{R}$ & $\mathrm{R}$ Square & $\begin{array}{c}\text { Adjusted R } \\
\text { Square }\end{array}$ & $\begin{array}{r}\text { Std. Error of } \\
\text { the Estimate }\end{array}$ \\
\hline 1 & $.751^{\mathrm{a}}$ & .563 & .552 & 3.09498 \\
\hline
\end{tabular}

a. Predictors: (Constant), Social Media Marketing

b. Dependent Variable: Brand Equitv

Sumber: Data diolah SPSS, 2019

\section{SIMPULAN}

Kesimpulan dalam penelitian ini yaitu social media marketing berpengaruh signifikan terhadap brand equity SMK Permata Harapan.

\section{UCAPAN TERIMA KASIH}

Peneliti mengucapkan terimakasih kepada semua pihak yang telah membantu dalam menyelesaikan penelitian ini.

\section{DAFTAR PUSTAKA}

Azman, H. A. (2019). Pengaruh Push Dan Pull Factor Terhadap Kunjungan. Benefita, 4(1), 182-195.

Kinanti, S. P., \& Putri, B. P. S. (2017). Pengaruh Media Sosial Instagram @Zapcoid Terhadap Brand Equity Zap Clinic. Jurnal Komunikasi, 9 (1),

JURSIMA https://ejournal.giciku.ac.id/ 
ISSN 2338-1523

E-ISSN 2541-576X

Volume 7 No. 1

Mei 2019

$53-64$.

Kusuma, B. A., \& Putri, B. P. S. (2019). Pengaruh Social Media Marketing Terhadap Brand Equity. Jim Upb, 7 (1), 33-37.

Noviani Sari Angkie, \& Tanoto, S. R. (2019). Pengaruh Social Media Marketing Terhadap Brand Equity Pada Brand Fashion Zara, H\&M, Pull\&Bear, Dan Stradivarius Di Surabaya. Agora, 7(1).

Nur Latifa Isnaini P, Fauziyyah, S., \& H, R. T. F. (2017). Peran Digital Marketing Terhadap Brand Equity Produk Pariwisata. In Snaper-Ebis (Pp. 406-410). Jember Indonesia.

Ratana, M. (2018). Pengaruh Social Media Marketing Terhadap Ekuitas Merek (Program Crowdscourcing Foto Periode 18 Juli 2016 - 2 April 2017 Di Instagram). Jurnal Studi Komunikasi Dan Media, 22(1), 1328.

Walid. (2018). Penggunaan Instagram
Sebagai Social Media Marketing Dalam Membangun Brand Awareness Platbm1912 Di Kota Pekanbaru. Jom Fisip, 5(1), 1-10.

Widyawati, A., \& Hidayat, R. (2018). Pengaruh Social Media Marketing Melalui Youtube Terhadap Tingkat Brand Awareness Pada Generasi Z. In E-Proceeding Of Applied Science (Vol. 4, Pp. 1226-1231).

Wulan, S., \& Dkk. (2016). Pengaruh Media Sosial Terhadap Brand Equity Universitas Bandar Lampung. Lampung Indonesia.

Zulfikar, A. R., \& Jurusan. (2017). Pengaruh Social Media Marketing Terhadap Brand Trust Pada Followers Instagram Dompet Dhuafa Cabang Yogyakarta. Jurnal Manajemen Dan Administrasi Islam, 1 (2), 279-294.

JURSIMA https://ejournal.giciku.ac.id/ 